\title{
Presidential Address, 2006 \\ Comparative Education in Changing Times: \\ A View with a Southern Exposure
}

\author{
Cecille DePass (University of Calgary)
}

\begin{abstract}
Adopting a wide angle lens to photograph selected educational vistas, the address also focuses on specificities associated with intractable challenges in comparative education. The paper offers a three part approach to discuss concomitant complexities: the first approach represents a well established historical tradition; the second, emphasizing interdependence, usually depicts the dominant mainstream perspective. In contrast, the third approach embedded in social justice, critical pedagogy, and opposition, demands significant structural changes. Understandably, the latter is the least likely to be adopted at regional, national and international levels.
\end{abstract}

\section{Résumé}

Se servant d'un objectif à grande ouverture pour photographier les vues choisies de l' éducation, ce rapport présidentiel se centre aussi autour des spécificités associées avec les défis complexes de l' éducation comparée. Il offre trois approches différentes pour discuter des complexités concomitantes: la première approche représente une tradition historique bien établie; la seconde, soulignant l’interdépendance, décrit souvent la perspective de la tendance dominante. En contraste, la troisième approche, se plantant dans la justice sociale, la pédagogie critique, et l'opposition, exige des changements structuraux significatifs. On comprend bien que cette dernière approche est la moindre à être adoptée aux trois niveaux régional, national et international.

Do you know why... the young sing?

Small songs without a sound?

(Escoffery, 1989, p. 69) ${ }^{1}$

The truism that comparative education is eclectic, evolutionary, interdisciplinary and multidisciplinary is demonstrated at annual CIESC meetings, where established and emerging scholars introduce new ideas, and, as importantly, showcase research conducted internationally and nationally. The field is exciting and dynamic. It ranges widely from educational reform (e.g. Zachariah, 1989, pp. 3-19; Maclure, 1993, pp. 69-89), to such specific areas as, indigenous (Kanu, 2005, pp. 1-20), multicultural (Bruno Jofre and Orteza y Miranda, 1999); immigration (Sloane-Seale, 2005, pp. 55-71) and citizenship (Sears \& Print, 1996; Hebért, Eyford, Jutras, 2005). Its strength, and flexibility are exemplified in papers presented at annual conferences; 2006 being no exception.

Comparative education, as we know, addresses formal (e.g. Wilson, 1990(a), pp. 61-89) and non-formal (Reimer et al, 1993, pp. 1-16) systems; 
policies (Wilson, 1990(b), pp. 32-49); programs, processes and practices (Mundy, 1993, pp. 22-44; Cheung et al 2000, pp. 87-104). Because of close affiliations with traditions of the social sciences, research is usually empirical. Due to increasing connections between education and the corporate sectors, several studies are commissioned by international development, public and nongovernment sectors.

CIESC's flagship, the CIE Journal, tends to focus on recent changes in educational systems in the south or north. Generally, very few articles explicitly incorporate theoretical or conceptual levels of analysis (notes, Majhanovich, 2003; Krugly-Smolska, 2003). Examples of explicit theoretical perspectives include that of Berry's typology (1994) classifying types of international development projects engineered by universities, and Shen's (1994) review of world systems theory. Krugly-Smolska (2003), in discussing the absence of explicit theories in papers submitted to the Journal, states that postmodern and postcolonial theories have challenged the explanatory stability of the classic structural functional and conflict theories. This address shows that theoretical influences are embedded within the research projects.

During the past winter, I have immersed myself in reading a sample of CIE's back issues. Previously, I have turned to the Journal for pragmatic purposes; however, perusing CIE's articles is similar to visiting and travelling with relatives and colleagues to new and well known regions. Offering a rich storehouse, CIE is full of intellectual treasures. Interesting scenes unfold, each rich with anticipated and unanticipated analyses which tend to challenge taken for granted notions in the field.

This address offers neither a full nor partial synthesis of CIE's history as reflected in its papers -- indeed, a formidable and daunting task. Instead, due to severe constraints, the paper highlights a few systematic problems primarily, in the south and some former colonial empires. It excludes special issues e.g., DePass, McNeill, and Zachariah (1991); Bruno Jofre and Orteza y Miranda (1999); McEwen (2002), as well as, the majority of articles published e.g., from Binda and Mzumara (1992) to Dhesi (2001). Accordingly, the paper depicts some snapshots of significant educational dilemmas on the international and national landscapes. The address highlights a few articles which either challenge some development myths, or insert a view or song of the south. (The original address, a far more detailed presentation, deliberately included several pictures, different voices, and pithy quotes, at strategic points to enhance the discussion. Another point of departure was the incorporation of poetry). Perhaps a second title for the paper could be the poetics of comparative and international education as sung by a southern voice.

For conceptual purposes, Hicks' model (1979) showing, in figure 1, fields of convergence and divergence (multicultural and development education) then has been modified by incorporation of key concepts from Freire (1978, 1982, 1987; hooks 1993, 1996, 2003, 2006); UNESCO (1994); CCUNESCO (meetings 2006), as well as the addition of a third field, that of comparative and international education (Figure 2). 


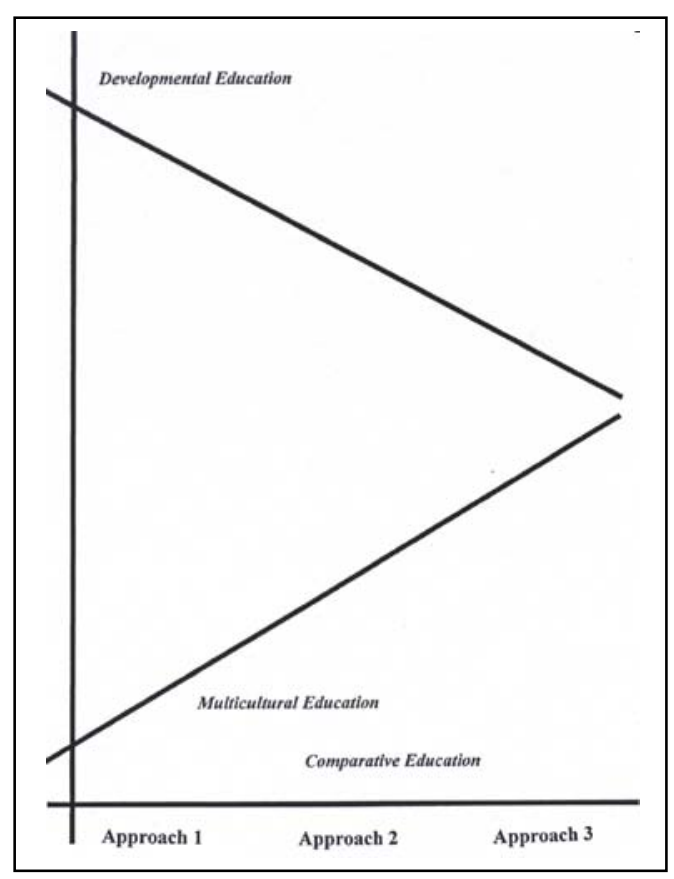

Following Hicks' model, for organizational purposes, the paper is divided into the following three parts. The first part representing one end of a continuum, identifies two works, London (1996) and Wright (1993), and then highlights major characteristics of Approach One.

Figure 1 - Modified Hick's model

Figure 2

Comparative Education: Emerging Themes

\begin{tabular}{|l|l|l|}
\hline APPROACH ONE & APPROACH TWO & APPROACH THREE \\
\hline$\gamma$ Problem Oriented & $\gamma$ Interdependence & $\gamma$ Development \\
& $\begin{array}{l}\gamma \text { Appreciation of Others } \\
\text { (Symbolic) }\end{array}$ & $\begin{array}{l}\gamma \text { Transformation (Self, } \\
\text { Community, Country) }\end{array}$ \\
\hline FOCUS & FOCUS & FOCUS \\
\hline $\begin{array}{l}\gamma \text { Problems caused by } \\
\text { 'Others' }\end{array}$ & $\gamma$ 'Human relations' & $\gamma$ Oppression \\
& Others & $\gamma$ Structural change \\
& $\gamma$ Contributions/ & $\gamma$ Changes in values \& \\
& Celebrations & \\
& $\gamma$ Modernization & \\
\hline PERSPECTIVE & PERSPECTIVE & PERSPECTIVE \\
\hline$\gamma$ Ethnocentric & $\gamma$ Tolerance & $\gamma$ Incorporate differences \\
$\gamma$ Eurocentric & $\gamma$ Living together & $\gamma$ Positive conflict \\
& $\gamma$ Integration & $\gamma$ Cultural \& ethnic autonomy \\
& $\gamma$ Reform system & $\gamma$ Radical change \\
\hline
\end{tabular}

Sources: hooks, 2006; Freire, 1970, 1982; UNESCO, 1994 
In the second part, Approach Two, characteristics of the new human capital model are explored through the eyes of Safr and Woodhouse (1996), Minnis (2000) and Shute (1995); followed with a more general discussion. Part Three, the far side of the continuum, draws on pieces by Dei (2000); Bruno Jofre and Henley (2002); and Dlamini (2001). Unabashedly, working within a southern perspective, the paper demonstrates key strengths and limitations of each approach. It shows that the First Approach has a well established historical tradition. In the author's view, the Second Approach, with an emphasis on expanded notions of interdependence, represents the dominant theoretical and applied perspective. In contrast, the paper shows that Approach Three, rooted in social justice, critical pedagogy, conflict and opposition, and demanding significant structural, systemic and individual changes, is the least likely to be adopted at national and international levels.

\section{Approach One: The Empire Lives}

1. London's (1996) study, an analysis of education in Trinidad (1938-1955), draws on the business language of quality control. It shows that a colonial education socializes British subjects to accept the social and economic hierarchy of empire. Education ensures that most students become manual labourers, and as importantly, accept the ruling groups' "inherent right to maintain their positions of dominance because they were culturally and even intellectually superior" (Bacchus, 1986, p. 21 in London; 1996, p. 46). By trickle up mechanisms, some individuals from the working classes may become school teachers and clerks in public service. Educational success is largely measured in terms of the ability to acquire the colonizers' culture.

Given school inspectors' perspectives, their evaluations in schools logs are congruent with the model of teaching basic skills and instituting screening procedures for selection of functionaries. Specific comments include: weak arithmetic; more practice in school English to reduce negative home influences; poetry taught to appreciate the beauty of English heritage; school gardens to inculcate manual labour skills; and poor discipline (p. 52). London asserts that inspectors record the school's failings. The school's role is to encourage cultural assimilation and "acceptance of the preferred canons of speaking and behaviour that would hopefully be firmly entrenched long after the dismantling of the colonial regime” (p. 55). He notes that school songs are from the English canon, and further that Trinidadian music is not taught.

London's paper demonstrates that evaluation has long been a central component of the practice of schooling. A recent article, in Alberta, for example, reports that some 450 teachers at the annual Alberta Teachers' Association conference, complained of the introduction (2005), of a US based personal digital assessment procedure in some public schools. Furthermore, teachers were not allowed to provide feedback, and expressed uncertainty concerning utilization of the information (Slade, Calgary Herald, May 23, 2006).

Raised in the British West Indies, perhaps London could have enhanced his argument with a more explicit Caribbean historical perspective. A colonial education in the West Indies has a well established historical mission -- spread of 
Christianity, acquisition of basic literacy and numeracy skills, production of a compliant, deferential labour force, and maintenance of a social and economic structure associated with a plantation society (Moore and Johnson, 2004, p. 210). By the mid 1930s continuing well into the 1970s, with few exceptions, a twotiered educational system had evolved. In Jamaica, for example, working class primary schools in tier one, as of the early to mid $19^{\text {th }}$ century, promoted loyalty to empire and, from the 1960s, to the Commonwealth (King, 1999, cited in Moore and Johnson, p. 231; Moore \& Johnson, 2004, p. 205). Several teacher training institutions (e.g. Mico Trust, 1834; Baptist, Calabar, 1842; Moravian, two schools, 1840, men; 1861 women; Roman Catholic, St. Joseph's College, 1897) established primarily by churches produced morally upright teachers/leaders (Moore and Johnston, 2004, p. 227). Funded by grants from churches, trust funds and fees, the second tier consisted of private preparatory and secondary schools for the middle classes. In this category of schools, British public school culture tended to be replicated. The intent was to civilize sons and, to a lesser extent, daughters of upwardly mobile blacks, creoles and poorer Europeans (King, 1999, cited in Moore and Johnson, p. 406).

Perhaps too, London has overstated his claim that imperial representatives anticipated the dissolution of empire. In the 1930s, prior to World War Two, it is unlikely that the end of empire or its entrenchment in the postcolonial era were conventional notions (Comment, Wilson, May 2006). On a personal note, in the late 1950s - 1960s, popular calypsos mocked the benefits of colonial education. Characteristics of the British model maintained well into the late 1970s include instructional pedagogies, syllabuses, texts, screening procedures to enter the traditional and comprehensive secondary schools and school leaving examination systems. It is possible that London's experiences underpin his claims of the enduring aspects of a colonial education. The effects of a colonial education -- devaluation, dismissal and denial of one's heritage, language and culture; and assimilation into the dominant colonial culture remain hot topics for debate (Notes from Maori Development Seminar, Victoria University of Wellington, August 2006). Yet in the Caribbean, neither schools nor churches were monolithic, total institutions, they unintentionally fostered resistance by for example, Paul Bogle, George William Gordon (mid 19 $9^{\text {th }}$ century), and in the $20^{\text {th }}$ century by Marcus Gravey, Norman and Michael Manley, Eric Williams, CLR James, Dereck Walcot, and Bob Marley.

2. Wright' s article (1993) shows that an attachment to the British Advanced Level examination still exists among high school students in Sierra Leone, despite the realization that the ' $\mathrm{A}$ ' level subject has no relevance to their future careers (p. 77). A few students state that only one Sierra Leonean author's work has been a prescribed text. Whether intentionally or unintentionally, students receive the message that Sierra Leonean literature is not 'worthy' of serious study (p. 82). The omission of Sierra Leonean texts in literature represents another form of the hidden curriculum. Wright suggests that poor performance in the Advanced Literature examination should be considered within the larger context of the type 
of literature taught, and punishments given for speaking one's mother tongue (pp. 84-85). Although discussing school students of the 1990s, Wright's paper supports key aspects of London's article. Thus the value of indigenous cultures largely remains unrecognized in the formal school curriculum. Even in postcolonial Sierra Leone, the school curriculum still contains vestiges of its colonial past.

\section{Approach One: Discussion}

Working within Approach One, generally policy makers and practitioners have tended to concentrate on 'problems' caused by 'others', namely, the significantly different people from the south, the non-EuroCanadian minorities. Target populations, ironically are people who live in most of the world who are not members of the elite, or dominant centre groups in their respective countries (Galtung, 1976). In a Canadian context, one may attribute social, political, and economic problems to groups such as indigenous peoples, members of ethnocultural groups, and people with disabilities whose failure to assimilate is usually traced to cultural, familial, or individual deficits. Yet, first nations peoples, for example, have largely survived the internal colonial agenda. Many, despite marginalization, have maintained their cultures (Aside: a university orator, when introducing an indigenous chief, the recipient of an honourary doctorate, describes the indigenous people as living in the shadows. Convocation notes, 2001).

For many ethnocultural groups, safe and celebratable expressions of symbolic ties to one's mother culture are usually folkloric expressions -- dress, diet, dance and dialect. Manifestations of such ties are seen, when Italy wins the World Cup (2006), and spontaneous crowds of Italian Canadians and their supporters pour onto the streets waving Italian flags. Such enthusiasm is allowed and greeted with tolerance and amused smiles by press representatives. Similarly, approximately twenty years ago, the Jamaican bobsled team (Winter Olympics, Calgary), won strong popular sentiment, and were depicted in a Disney comedy "Cool Runnings" (still aired on TV, spring 2006). In many Canadian cities, cultural diversity is seen to be safe, as long as celebrations of diversity neither impede nor restrict the day to day business of the state or the marketplace. Accordingly, symbolic ties are welcomed in Carifest, Cariwest, Caribana, Heritage Day and Canada Day celebrations. For short periods, in controlled places, lines are blurred as 'we and they meet, mingle, and jam'. Smells of ethic foods and sounds of ethnic music are among the safe reminders of diversity.

A 'we they' dichotomy may be reinforced, however, if distinctions concerning the 'we' group, are highly nuanced in a manner similar to fine photographs in which gradations within colour, perspective, and representation are meticulously portrayed. Under such conditions, generally differences within the 'we' group tend to be tolerated, welcomed and even accepted. As part of the 'we' group, we may look through benignly coloured glasses at the characteristics of real, imagined, and 'wannabe' members of our group. Sometimes, working with members of our group we may adopt, on one hand, benevolent, indulgent, or on 
the other, kindly and more generous attitudes and behaviours. Yet at other times, depending on perceived and real power differentials, we may adopt more distant, tolerant, or conditional attitudes of acceptance. An analogy from large extended families, is perhaps, the manner in which one's older cousins, uncles, aunts, and grandparents treated our siblings and ourselves when we were young. However, despite the behaviours, there is little doubt in our minds that we belong. In a liberal sense, to be a member of the 'we' group means that our differences are usually seen as contributing to the well being and survival of the larger group.

In order to distinguish between the merits of one side over the other, in a 'win lose', or 'we they' perspective, we tend to demarcate careful boundaries between our side and the other side(s). In an international setting, one talks about the south and the periphery of the periphery (Galtung, 1976). Within this context, euphemisms such as third world can be demeaning to people who live in the south (Pieters and Parekesh, 1995). As a doctoral student once said to me, 'We are called developing and underdeveloped. It is as though economic development in western terms is a measure of our human, cultural, spiritual and emotional development.'

Poonwassie's paper (1995) regarding the nature of tolerance seems particularly applicable to a discussion of school curriculum and texts. At first glance, the concept appears to be rather benign and embraces elements of forgiving the other; however inherent concepts are also condescension, and superiority on the part of the tolerator (p. 2). Conditions for tolerance are grounded in sets of relationships, firstly, respect for self and others, and secondly, disapproval, dislike, and disgust where disparities between groups are significant. Tolerance requires understanding, based in knowledge, appreciation, affirmation, and the celebration of life-enhancing human qualities (p. 5). These, then are a few of the challenges faced by curriculum makers in the south who have inherited colonial forms of education from Britain, Portugal, Spain, Holland and France.

\section{Approach Two: 'Be Careful What We Wish For'}

1. Safr and Woodhouse's (1996) qualitative study, explores teachers' responses to major structural changes, namely, the introduction of liberal educational reforms in the Czech Republic. The changes are designed to encourage "free and independent thinking”, and "to inspire students" (p. 100). Given the rigid culture of silence imposed in the former soviet empire, the tensions identified by teachers are not surprising. Although there is freedom of choice concerning selection, for example of, mathematics texts. Teachers indicate that they lack the skills to integrate students' lived experiences with abstract math concepts (p. 106). Furthermore, under the old regime, mathematics and science were emphasized; however, the shift to a free market economy, tends to emphasize law, business, and medicine. Accordingly, a decline in the importance of math has occurred (p. 105). Also noted, is the introduction of small group activities for singing and music (p. 105); whereas, in the past, schools had a reputation of fostering individual excellence in the performing arts. 
Perhaps the greatest change, according to the authors, has been the movement from a rigid statist, Marxist ideology to that of a more laissez faire, market driven system. In the past regime, school knowledge was received without question, and problem posing/problem solving activities were not prescribed. Presently, without communiqués from central office, teachers ask how to inspire and encourage critical thinking and creativity. In the new society, education is equated, for the most part, with commercialization and assimilation to the values of the marketplace. The authors conclude with a discussion of challenges to teacher education and the need to develop a more liberal educational model.

2. In light of the continuing economic boom in Alberta, in the early 2000s, and deployment of military forces to Afghanistan and parts of the Middle East, post 911, I was drawn to Minnis' (2000) critique of significant imbalances in OPEC countries (during the late 1990s). Minnis identifies limitations of the trickle down theory, by questioning one version of the human capital model, namely, educational expenditure in OPEC's "petrocultures". His discussion of exacerbation of social inequalities, uneven economic development, and the increasing external indebtedness of Middle East countries, are surprising (Minnis, citing Amuzegar, 1999, p. 171). The paper reveals an economic development paradox, that increased expenditure on physical infrastructure and communications is not synonymous with increased economic productivity. When one considers the vast accumulation of wealth, and sizeable investments in infrastructure, it is disconcerting to note that productivity has not significantly increased. Reasons include: stagnant or declining productivity, mismanagement, and an absence of structural reforms. In what Minnis describes as "a paradox of plenty", there are high levels of investment in education, low economic productivity, and growing social inequalities.

Minnis contests the belief that an investment in education, in particular in regions with strong economic growth, is accompanied by social equality, and economic diversification (p. 19). To the contrary, social and economic imbalances have deepened due to high military expenditure and heavy foreign debts (p. 20). In schools, dropout and repeater rates are consistently high. Technical and vocational institutions are underutilized, despite sizeable investments. Graduates tend to shun technical and manual jobs (p. 21). Far more interest exists in an elite, academic education than in a technical education. Accordingly, imbalances between the types of graduates and the types of work are also noted. As a result, there are high rates of unemployment among secondary graduates. Finally, huge capital investments in human resources tend to remain unrelated to the needs of the domestic market (p. 21). Minnis' paper reiterates dilemmas of high educational expectations and aspirations for white collar jobs held in many postcolonial countries in the south.

3. In contrast, Shute's small case study (1995) is a far more positive review of the development of human resources at Universities of Guelph and Ghana. His is a retrospective examination, 15 years after project completion. Designed to 
strengthen several departments of the Ghanaian University, comprehensive project objectives range from graduate degree training, short term training of technicians, visiting fellowships for senior Ghanaian faculty, library support, provision of teaching and research equipment to staggered posting of some 24 Canadian academics to the university. 44 Ghanaian graduate students, technicians and research fellows studied at the Universities of Guelph, British Columbia and Manitoba.

Shute's paper speaks to the subsequent development of national factors, beyond the control of the project. By the late 1980s, post project completion, due to national political and economic problems, the survival was questioned of several associated project departments and programs. Accompanying the uncertainty was the short term migration to other African countries of large numbers of trained people. Despite setbacks, a survey of original project participants conducted in 1994 by a colleague identifies several positive impacts. Some examples include: most graduates have returned to the home university; a few are employed in other Ghanaian universities; a few have accepted senior posts in public, private and non-government sectors. A few have migrated to countries elsewhere in Africa, and at least one became a senior research scientist in India (pp. 87-88, detailed discussion). All four Ghanaian research fellows have returned to senior posts at the home university. Positive effects on the lead Canadian university include establishment of international development programs; consulting assignments; and career mobility for some faculty (p. 90). Shute concludes that by any standards of evaluation the project has been a success.

\section{Approach Two: Discussion}

Multi-layered notions of interdependence now move to the centre of the picture. Explicit and implicit objectives for the recipient country or region are the transfer of the knowledge, technology, infrastructure, and expertise from the north (Berry, 1994; Shute, 1995; Kealy, 1990). From the donor's perspective, technical expertise of professionals is not enough; as important, are skills to teach, train, and communicate; abilities to understand the others' world views, and to make oneself understood, (Kealy, 1990). Perhaps, at more intangible levels, for the project to be successful, one includes learning about self and other, dispelling negative stereotypes and myths of others, and ultimately, learning how to live together peacefully. Given the increased movements of capital, labour, introduction of structural adjustment programs, and continuing disparities between north and south, not made explicit is whether long-term survival is possible for smaller fragile, vulnerable economies, particularly in the south, which have been continuously buffeted, internally and externally, by major economic, political, and social changes for hundreds of years (Levitt, 2005; Wright, 1997).

Interdependence is explicit and implicit in the development education literature (e.g. Reimer et al, 1993; conversations Zachariah, 1988). In Canada, acceptance of others, and other cultures, is promoted, by teaching classes in international development, global and development education; and designing and delivering workshops in fields such as race relations, intercultural, and cross- 
cultural communications. An underlying assumption is that by learning minority perspectives of histories, struggles and triumphs, then we may learn to understand and appreciate significantly different cultural, racial and national groups.

Cornerstones of the second approach are evolving concepts of respect, acceptance, dignity and human rights (Poonwassie, 1995; conversations Dolakia, 1992). We learn that our world view is not accepted by others who live in the same family, let alone shared by people who live in different countries. Liberal formal and non-formal educators suggest that other groups of people have developed/are developing: world views; ways of living, being; making decisions; governing and following which are significantly different to our own. Hopefully too, we learn from elders and peers, how to avoid prejudging others based on our own systems of values. In the second approach one moves beyond merely practicing tolerance (Poonwassie, 1995). One encourages more than a limited recognition of the manner in which one's ideas, one's way of life, and one's society may be viewed from another vantage point. One encourages students to learn how to think like the other, and to find commonalities with the other. However, understanding the other should not become a strategy for manipulation, domination, control and ownership of the other.

Interdependence, to be mutually beneficial, must have a synergistic, fluid yin yang relationship. In this view, interdependence runs like a mighty river. It means that all members of a society from the individual, to the family, to even more abstract operations of socio-economic and political systems draw from, and contribute positively and negatively to the well being or ill health of all. Each of us, either collectively and/or independently, has the power to contribute, in small or major ways, to conditions in which all cultures, peoples, geographic and manmade regions and states, share a sense of collective survival or collective destruction.

Understandably, this idealistic view of interdependence means far more than trying to solve educational problems by transferring predetermined models and technologies from north to south. It means creating a spirit of 'weness' in the finest sense of the term; not 'we/theyness' when collaborating in activities with poor and displaced people. It means examining distributions of power and inequalities individually, locally, regionally and globally. It involves asking pretty tough questions, such as, how is power used and abused? Are notions of power seen to be power over, or power with? How do members of dominated groups comply with dominant groups in every day interactions? Can dominant and dominated groups work together in mutually beneficial ways in order to develop new strategies without resorting to power struggles between groups as demonstrated in the classic conflict perspective? Happily, this work has begun. 


\section{Approach Three: The Empire's New Clothes}

1. In critiquing reforms introduced by international agencies in West Africa, Dei (2000) reminds the reader that organizations such as UNDP and UNICEF often specify the required educational changes as a condition of granting financial assistance. In doing so, countries dependent on foreign capital to finance local initiatives are restricted by conditions imposed by international agencies. Within the larger picture of structural adjustment programs introduced in the south, economic organizations such as the IMF and World Bank, wield far reaching power. Schooled in the south, Dei, uses a similar perspective to London and Wright (cited earlier). He argues that the colonial educational model designed to create cheap labour, largely remains intact (p. 39).

In Sierra Leone's budget, military expenditure has dominated the allocation of financial resources. More recently, at least one NGO, has introduced a non-formal education program to rehabilitate some male teenage soldiers (Shepler, 2005). While in Ghana, prioritization has meant the redistribution of resources at the expense of education. Educational reform situated within the rhetoric of modernization tends to be insufficient and its changes are at best, ambiguous and ambivalent (p. 40). As a result, most Ghanaian students learn neither basic, nor western curriculae, let alone that of postcolonial curriculae designed to legitimate indigenous knowledge and histories (Dei, p. 69; See also Dei and Asgharzadeh, 2004).

2. Bruno Jofre and Henley (2002) posit that the current crisis of capitalism is similar to that of the late $19^{\text {th }}$ century; however, a major difference is that public education has become a site for increasing private sector investment (p. 1). Indicators cited include: creation of professional associations for private teachers; introduction of private sector [tutoring companies] for public consumption; increase in numbers and types of charter schools [e.g. arts, religious, gifted]; introduction of online learning systems (e.g. smarter kids.com, and Blackboard, p. 7).

Educational services for profit range widely from testing to educational management. In this perspective, the new human capital model represents a close correlation between schools and marketplace. Thus, students have become consumers; customer satisfaction is to be guaranteed; and education and its associated services have become commodities to be traded on the market (p. 10). Such a view has major implications for educational systems at home and abroad (e.g. extension of distance learning services to the south via internet; creation of university branch campuses/offices in major Chinese economic growth centres; email, Luu, June 2006); and possibly, negative impacts on some southern universities, due to migration to the north of sizeable numbers of southern students (notes, CCUNESCO meeting, May 2006).

3. Dlamini (2001) moves the discussion from an emphasis on systems to a rich level of specificity in her analysis of daily negotiations of power by university students. Of note, is her reference to Phoenix (1997) that there is a systematic lack of the "recognition of historical power relations between black and white 
people; a denial of power emanating from a refusal by whites to be positioned as beneficiaries of historic injustices such as the slave trade; and because of a general failure by the dominant to reflect on dominance" (p. 67).

Dlamini's paper explores responses of EuroCanadian students who position her (the university professor) as disadvantaged and marginalized. Discussing her own schooling, she traces the effects of her family's socioeconomic and cultural capital, coupled with her privileged position, aptitudes and abilities which promoted excellence. Critical pedagogy adopted in her teaching, entails "[writing] herself into the university classroom". The students, however, are reluctant to identify their own privileged status and related power, accordingly, white privilege remains invisible (p. 77). As long as, perspectives, resources, and class discussions reinforce EuroCanadian patterns of dominance, opposition to her presence, texts and teaching strategies, tend to remain underground (p. 80). Dlamini's analysis of her teaching experiences in Halifax, exemplifies the problems of a critical minority woman academic who tries to engage EuroCanadian women and men student teachers in discourses concerning the imbalances in privilege, dominance and power.

\section{Approach Three: Discussion}

The third approach concentrates on major structural changes. For some, social justice, critical pedagogy, positive conflict, and opposition are explicit issues at the forefront of the comparative education picture. Largely determined by specific contexts, individual, community, national, and international development take on significantly different meanings (Levitt, 2005). Starting with one's self and the persons with whom we live, work, go to conferences, share our dreams, hopes, fears, and aspirations; we begin to name, explore, resist, and may even dare to question visible and invisible systems of dominance and oppression in our daily lives (e.g. Haig Brown, hooks, Lee, Bannerji, Giroux, Said, Silvera and Srivastava). Understandably, there is a considerable cost if one becomes an oppositional academic (e.g. Dlamini, 2003; hooks, 2006; Freire, 1987, to name a few).

Indeed, using Freirie's and hooks' approaches of identifying key concepts and significant themes which resonate with one's daily life, students, teachers and professors would work together, with and through dialogical processes in order to interrogate seemingly, neutral discourses. We would have conversations based on a respectful, dignified, and affirming reciprocity between "I" and "Thou". We would examine questions such as: Whose knowledge have we excluded either deliberately or unintentionally? Knowledge for what purpose, to what end? ${ }^{2}$ Education for whom, and for what purpose? Research to what end, for what purpose? Who benefits most from the manner in which information is constructed, generated, disseminated, and sold at a profit?

Admittedly, in addressing even a few of the issues we are grappling with some of the larger questions posed by Escoffery's quote at the beginning of the address. Within the formal curriculum of the university and international development educational projects: Whose knowledge and whose potential is 
encouraged, valued and validated? Whose knowledge is devalued and whose life chances and potential are stifled? Whose spirit is broken, mended, and healed? Who lives and who dies? Yet critical educators (e.g. Ratna Ghosh, Henry Giroux, Edward Said, Paulo Freire, Enid Lee, Celia Haig Brown, Nombuso Dlamini, Ali Aabdi, George Dei, and Martin Luther King III) believe in human abilities to transform ourselves and our world in positive ways. It is for these reasons that approaches to comparative education, usually hover somewhere around the midpoint, which I have called Approach Two. As members of CIESC, I urge us to work together unstintingly as sisters and brothers. Let us create a fairer, more equitable world in which children everywhere, for generations to come are valued, honoured, treasured and able to live together in peace.

...It's the children

that laugh

It's the children

that die...

When tomorrow approaches

and we will have died,

It's the children whose peace

we will have denied.

(Goulbourne, 1989 in Mordecai, p. 95).

\section{Notes:}

1 Dedication to David Wilson, my family, friends, colleagues and children everywhere.

2 The 1989 World Congress, Montreal, hosted by Canada, was perhaps, the first time when scholars from the south were deliberately encouraged by the Canadian organizers to take an active part in the conference (Notes from CIESC AGM, Laval, 1989). The organizers of the World Congress, 2004, Havana Cuba, also made every effort to solicit participation of academics from the south (Notes, Report from Organizing Committee, Executive Meeting, World Council of Comparative Education Societies, Stanford University, March 2005). 


\section{References}

Abdi, A. and Ghosh, R. (2004). Education and the Politics of Difference: Canadian Perspectives. Toronto: Canadian Scholars Press.

Amuzegar, J. (1999). Managing the oil wealth: OPEC's windfalls and pitfalls. London: IB Tauris in Minnis (2000), p. 21.

Bacchus, M.K. (1986). The Myth and Reality of Curriculum Planning: Insights from Educational Development of the Caribbean. London: Institute of Education. In London (1996).

Berry, J. (1994). Sharing Whose Future? Canadian Universities and International Cooperation. Canadian and International Education, 23(1), 25-41.

Binda, K.P. and Mzumara, P.S. (1992). Job Performance of Inservice Trained and Untrained Elementary School Principals in Malawi. Canadian and International Education, 21(1), 55-63.

Bruno Jofre, R. and Henley, D. (2002). The Canadian Education Industry: An Historical Critique of Education as Merchandise. Canadian and International Education, 31(1), 1-18.

Bruno Jofre, R. and Orteza y Miranda, E. (Guest Editors). (1999). Special Issue, Multiculturalism. Canadian and International Education, 28(2).

Cheung, D., Ng, D., and Hattie, J. (2000). The Simplex Structure of Teachers' Stages of Concern About Implementing a New Curriculum. Canadian International Development Agency, 29(1), 87-104.

Dei, G.J.S. (2000). Local Knowledges and Educational Reforms in Ghana. Canadian and International Education, 29(1), 37-72.

Dei, G.J.S. and Ashgharzadesh, A. (2004). Inclusive Education and Social Development in an African Context. Canadian and International Education, 33(2), 1-30.

DePass, C., McNeill, J. \& Zachariah, M. (Guest Editors). (1991). New Challenges for Development Education in Canada in the Nineties. Canadian and International Education, 20(1).

Dhesi, A. (2001). Determinants of Post-School Choice in India - A Discriminant Analysis. Canadian and International Education, 30(2), 35-64.

Dlamini, N. (2001). Can the Empire's Tools ever Dismantle the Empire's House? Teacher Education and the Practice of Identifications. Canadian and International Education, 30(2), 65-89.

Escoffery, G. (Spring, 1989). In Mordecai, P. (Ed.), From Our Yard: Jamaican Poetry Since Independence. Kingston: Institute of Jamaica, p. 69.

Freire, P. (1982). Education for Critical Consciousness. New York: Continuum Publishing Corporation.

Freire, P. (1978). Pedagogy in Process. London: Writers and Readers Publishing Corporation.

Freire, P. (1987). Pedagogy of the Oppressed. Harmondsworth: Penguin.

Galtung, J. (1976). A Structural Theory of Imperialism in Barclay W., Kumar, K. and Simms, R. (Eds.). Racial Conflict, Discrimination and Power: Historical and Contemporary Studies. New York: AMS Press, pp. 391-418.

Goulbourne, J. (1989). It's the Children. In Mordecai P. (Ed.), From Our Yard: Jamaican Poetry Since Independence. Kingston: Institute of Jamaica, p. 95.

Hébert, Y., Eyford, G., and Jutras, F. (2005). Special Issue, Values, Human Rights, and Citizenship Education in Transnational Perspectives. Canadian and International Education, 34(1). 
Hicks, D. (1979). Two sides of the same coin: An exploration of links between multicultural education and development education. The New Era, 61(2).

hooks, b. (1996). Bone Black: Memories of Girlhood. New York: Henry Holt and Company.

hooks, b. (2006). Love Fights the Power. Shambhala Sun, July, pp. 58-63.

hooks, b. (1993). Sisters of The Yam: Black Women and Self Recovery. Toronto: Between the Lines.

hooks, b. (2003). Teaching Community: A Pedagogy of Hope. New York: Routledge.

Kanu, Y. (2005). Decolonizing Indigenous Education. Beyond Culturalism: Towards Post-cultural Strategies. Canadian and International Education, 34(2), 1-20.

Kealy, D. (1990). Cross-Cultural Effectiveness. Hull: Canadian International Development Agency.

King, R. (1999). Education in the British Caribbean. In Miller, E. (Ed.), Educational Reform in the Commonwealth Caribbean. Washington, DC: Organization of American States.

King 1ll, M.L. (2006). Pathways to Peace. Keynote presentation, International Peace Conference, University of Calgary, July.

Krugly-Smolska, E. (2003). Where's the Theory? Canadian and International Education, 32(1), v-x.

Lee, E. (2006). 'Talk to me, brothers and sisters': Black Educators' Perspectives on Professional Development and Organizational Contexts for Anti-Racist Education and Change. Draft, PhD Manuscript. U of Toronto/OISE.

Levitt, K. (2005). Reclaiming Development: Independent Thought and Caribbean Community. Kingston: Ian Randle Publishers.

London, N. (1996). Quality Control in a Colonial School Setting: How it Worked and for What Purpose? Canadian and International Education, 25(1), 43-61.

Majhanovich, S. (2003). Making Sense of Decentralization in Education Using a Comparativist Lens. Canadian and International Education, 32(1), 1-18.

Maclure, R. (1993). School Reform in Burkino Faso: the Limited Prospects of Decentralization and Local Participation. Canadian and International Education, 22(2), 69-89.

McEwen, N. (Guest Editor). (2002). Special Issue International Comparison of Educational Systems. Canadian and International Education, 31(2).

Minnis, J.R. (2000). Education in the Rentier State: Patterns and Problems. Canadian and International Education, 29(1), 17-37

Moore, B. and Johnson, M.A. (2004). Neither Led nor Driven: Contesting British Cultural Imperialism, 1865-1920. Mona: University of the West Indies Press.

Mundy, K. (1993). The Case of Universal Primary education revisited: The Tanzanian and Zimbabwean Experience in Canadian and International Perspective. Canadian and International Education, 22(1), 22-44.

Pieterse, J.N. and Parekh, B. (1995). The decolonization of the Imagination: Culture, Knowledge and Power. London: Zed Books.

Phoenix, A. (1997) “I'm white, so what?” The Construction of Whiteness for Young Londoners. In Fine, M., Powell, L.C., Weis, L., and Mun Wong, L. (Eds) Off White: Readings of Race, Power and Society. New York and London: Routledge. In Dlamini, p. 67.

Poonwassie, D. (1995). Tolerance. Canadian and International Education, 24(2), 1-13. 
Reimer, R.K., Shute, J.C.M., McCreary, E.K. (1993). Canadian Non-formal Development Education: A typology of Educational Strategies. Canadian and International Education, 22(1), 1-16.

Safr, V. and Woodhouse, H. (1996). Eastern, Western, or Pan-European: Recent Educational Change in the Czech Republic. Canadian and International Education, 25(1), 100-121.

Sears, A. and Print, M. (1996). Special Issue, Citizenship Education: Canadian and International Dimensions. Canadian and International Education, 25(2).

Shen, J. (1994). Nation-state Approach and World Systems Analysis: A New Perspective on Comparative Education. Canadian and International Education, 23(2), 1-12.

Shepler, S. (2005). Formal and Non-formal Education in the Rehabilitation of Former Child Soldiers in Sierra Leone: A Dichotomy Resolved in Practice. Paper presented at Comparative and International Education Society, March 2005, Stanford University.

Shute, J. (1995). Assessing the Medium-Term Impact of an Institutional Strengthening Project. Canadian and International Education, 24(2), 85-94.

Slade, D. (2006). Drive by grading angers teachers. Calgary Herald, May 23, pp. B1-B2.

Sloane-Seale, A. (2005). New Immigrants' Barriers to participation in Society and the New Economy. Canadian and International Education, 34(2), 55-71.

UNESCO (1994). A Culture of Peace: Draft Report.

Wilson, D.N. (1990a). A Comparative Study of Open Universities in Thailand and Indonesia. Canadian and International Education, 19(2), 61-86.

Wilson, D.N. (1990b). The Deleterious Impact of Return Studies on LDC Educational Policies: An Indonesian Case. Canadian and International Education, 19(1), 32-49.

Wilson, D.N. (1994). What Education and Training for which Future? A Comparative Perspective. Canadian and International Education, 23(2), 77-63.

Wright, H.K. (1993). What is Shakespeare Doing in My Hut? 'A' level literature and the Sierra Leonean student. Canadian and International Education, 22(1), 66-85.

Wright, J. (1997). Deconstructing Development Theory: Feminism, the Public/Private Dichotomy and Mexican Maquiladoras. Canadian Review of Sociology and Anthropology, 34(1), 71-92.

Zachariah, M. (1989). People's Movements and Reform of Formal Education: Reflections on Kerala Sastra Sahitya Parishad (KSSP) in India. Canadian and International Education, 18(1), 3-19.

Cecille DePass, professor at the University of Calgary (Faculty of Education) is presently, Chair/President, CCUNESCO; Past President, CIESC (2003-2005); Director, CSSE, and former, Associate Director, Research, Cultural Diversity Institute. Originally a Commonwealth scholar, her research interests tend to be grounded in critical and postcolonial theory and concentrate on social justice, multiculturalism, and equity for minorities. 